\title{
Democratisering van de technologische cultuur
}

\author{
Citation for published version (APA):
}

Bijker, W. E. (1995). Democratisering van de technologische cultuur. Schrijen-Lippertz. https://doi.org/10.26481/spe.19950324wb

Document status and date:

Published: 24/03/1995

DOI:

10.26481/spe.19950324wb

Document Version:

Publisher's PDF, also known as Version of record

\section{Please check the document version of this publication:}

- A submitted manuscript is the version of the article upon submission and before peer-review. There can be important differences between the submitted version and the official published version of record.

People interested in the research are advised to contact the author for the final version of the publication, or visit the DOI to the publisher's website.

- The final author version and the galley proof are versions of the publication after peer review.

- The final published version features the final layout of the paper including the volume, issue and page numbers.

Link to publication

\footnotetext{
General rights rights.

- You may freely distribute the URL identifying the publication in the public portal. please follow below link for the End User Agreement:

www.umlib.nl/taverne-license

Take down policy

If you believe that this document breaches copyright please contact us at:

repository@maastrichtuniversity.nl

providing details and we will investigate your claim.
}

Copyright and moral rights for the publications made accessible in the public portal are retained by the authors and/or other copyright owners and it is a condition of accessing publications that users recognise and abide by the legal requirements associated with these

- Users may download and print one copy of any publication from the public portal for the purpose of private study or research.

- You may not further distribute the material or use it for any profit-making activity or commercial gain

If the publication is distributed under the terms of Article $25 \mathrm{fa}$ of the Dutch Copyright Act, indicated by the "Taverne" license above, 


\title{
Democratisering van de Technologische Cultuur
}

\author{
Rede \\ in verkorte vorm \\ uitgesproken bij de aanvaarding van het ambt van \\ gewoon hoogleraar Techniek \& Samenleving \\ aan de Faculteit der Cultuurwetenschappen, \\ Rijksuniversiteit Limburg te Maastricht, \\ op vrijdag 24 maart 1995 \\ door
}

Wiebe E. Bijker 
Aan de nagedachtenis van Greetje Bijker-Jellema 
Mijnheer de Rector Magnificus, geachte collegae, studenten, toehoorders,

"In oude tijden had je tovenaars; en de moderne mensheid denkt, dat de tijd van toveren voorgoed voorbij is. Maar net zoals in oude, onbeschaafde tijden het ene land meer regenmakers had en het andere meer sterrenwichelaars, zo hebben de landen ook vandaag nog speciale soorten tovenaars. Nederland bijvoorbeeld heeft geen regenmakers nodig; het regent er heel veel." Zo begint Den Doolaard (1948: 9) zijn sleutelroman over de sluiting van de gaten in de dijken van Walcheren. Nederland heeft, vervolgt hij, een speciaal soort tovenaars: watertovenaars. "Van wat die watertovenaars doen, begrijpen de mensen weinig of niets. Maar dat geeft niet. De hele moderne maatschappij berust nu eenmaal op het vertrouwen van de gewone mensen in de tovenaars. En iedereen die in Nederland beneden de waterspiegel woont laat in blind vertrouwen de tovenaars-waterbouwkundigen aan de dijken ploeteren." Wat een vertrouwen in de dijken, wat een vertrouwen in autoriteiten, wat een vertrouwen in wetenschappelijk-technische expertise spreekt hieruit-de jaren ' 90 zijn hier duidelijk nog niet aangebroken, de jaren '70 hebben we ook nog niet gehad, en het is zelfs nog geen 1953.

Op 1 februari 1953 kwam er nog geen barstje in dit vertrouwen, maar braken wel de Nederlandse zeedijken. Een timmerman in Stavenisse, Tholen, herinnert zich: "Ik zei tegen vader: 'Daar komt het water, hoor.' Hij vroeg nog: 'Komt het water dan in huis?' Ik zeg: 'Ja, de kelder loopt al vol, ga dus maar naar boven.' Maar toen tegelijkertijd, ja, toen kwam er een donderend geweld. Toen braken er een paar gaten in de zeedijk van de Oosterschelde en dat was dus aan de westzijde van het dorp. (...) Maar bijna op hetzelfde moment schoof er over een lengte van ongeveer achttienhonderd meter heel de dijkkruin af onder die muur van water. En toen kwam die muur van water op het dorp afstormen. Een muur van twee meter hoogte. Ja, dat was gewoon een zondvloed, laat ik het zo maar zeggen."1 Juist in die eerste paar uren zijn de meeste van de in totaal 1835 slachtoffers 
verdronken. Nederland zette zich schrap. Met een zeldzame eensgezindheid van parlement tot individuele burger werd tot een ingrijpende, technisch zeer geavanceerde verandering van Nederland besloten-en deze veranderingen betroffen zowel de fysisch-geografische, als de sociaal-culturele, organisatorische, en waterbouwkundige kanten van ons land.

$\mathrm{U}$ weet hoe dat verder is gegaan. ${ }^{2}$ Twintig jaar later, in de jaren '70, stond de Nederlandse democratie op haar grondvesten te schudden. Heel de samenleving was gespleten-van regering en parlement tot de gezinnen van de watertovenaars. De oplossing kwam langs een weg die niet te begrijpen valt zonder inzicht in de Nederlandse technologische cultuur. Een cultuur waarin men een dijk kan bekijken en verzuchten: "Lekker [ligt] hij er bij: zeven meter hoog, en een smak zand ervoor". ${ }^{3}$ Nederland sloot de rijen rondom een half-open dam in de Oosterschelde-een constructie die er nooit zou komen maar wel een ingrijpende rol in het democratisch proces heeft gespeeld. In 1986 werd een andere constructie, de Oosterschelde-stormvloedkering, door de Koningin in bedrijf gesteld, en hij doet het nog steeds.

Maar een cultuur is niet statisch, symbolen veranderen, waarden verschuiven. De rijswerkers van Werkendam wisten het vroeger wel, zoals hun apocriefe gebed het zei: "Heer, geef ons heden ons dagelijks brood, en elk jaar een watersnood." Zonder die regelmatige herinnering aan de dreiging van het water zouden de Nederlanders, dachten de Werkendammers, hun dijken verwaarlozen en de rijswerkers hun broodwinning verliezen. Dijken worden dan landschapselementen, ecologische niches of esthetische objecten. Watertovenaars worden techneuten en cultuurvernielers.

Over dit soort thema's wil ik het vandaag met $u$ hebben. Eerst over de lof der techniek en de tyrannie der techniek; over de schuivende grenzen tussen de natuur en de techniek, tussen het technische en het sociale; over, zal ik zeggen, technologische cultuur. Het tweede thema betreft ons leven in die technologische cultuur: hoe geven wij haar vorm, hoe reageren we op schending ervan, hoe helpt zij ons tegen bedreigingen van buiten; hoe, kortom, richten wij onze democratie in? 


\section{Wij leven in een technologische cultuur}

Wij leven in een technologische cultuur. Natuurlijk, we leven ook in de natuur, omringd door kunst, politiek bedrijvend en beelden scheppend-maar in deze rede zal ik vooral de observatie uitwerken dat we leven in een technologische cultuur. ${ }^{4}$

Op het eerste gezicht is "technologische cultuur" een contradictio in terminis. Als iets elkaars tegengestelden zijn, dan wel technologie en cultuur. Neil Postman (1992) spreekt over "technology's intrusion into a culture", over "tools [that] are not integrated into the culture [but] attack the culture", uiteindelijk resulterend in "the surrender of culture to technology." De utopist en 19e-eeuwse sociaal-criticus Samuel Butler beschrijft een maatschappij waarin men besloten heeft alle machines uit te bannen. De hoofdpersoon van het boek, die per ongeluk in deze samenleving verzeild raakt, wordt gearresteerd omdat hij een horloge draagt. Hij ontdekt dat dit uitbannen van technologie is gebeurd nadat "one of the most learned professors (...) wrote an extraordinary book (...) proving that machines were ultimately destined to supplant the race of man, and to become instinct with a vitality as different from, and superior to, that of animals, as animal to vegetable life" (Butler, 1872 (1983): 97).

Mijn invalshoek staat hier haaks op. Ik ga niet uit van deze tegenstelling techniek-cultuur, maar neem "technologische cultuur" als de eenheid van analyse. Dat heeft niet alleen methodologische en inhoudelijke, maar-zoals later zal blijken-ook politieke consequenties.

\section{methodologische en inhoudelijke implicaties}

Wij leven in een technologische cultuur. Als ik mijn uitgangspunt op deze manier formuleer, dan impliceert dat allereerst een methodologische stellingname. Wij leven in een complexe, hoogontwikkelde samenleving die we op verschillende manieren kunnen proberen te beschrijven en begrijpen. Eén van deze manieren is haar te benaderen via de kant van technologische cultuur. Een dergelijke benadering stoelt op de erkenning dat alle vijf hiervoor genoemde karakteriseringen van onze cultuur verwijzen naar belangrijke kanten van de moderne samenleving en daarom even- 
zovele vruchtbare ingangen voor analyse vormen. Het zijn echter karakteristieken van deze moderne samenleving en, in mijn visie, niet afzonderbare of zelfs maar onderscheidbare maatschappelijke subsystemen. ${ }^{5}$ Door "technologische cultuur" als eenheid van analyse te nemen wordt essentialisme in de analyse van techniek en cultuur vermeden en kan ik juist onderzoeken hoe in de technische, sociale en politieke praktijk de grenzen tussen cultuur en techniek steeds op strategische manieren anders worden getrokken.

Dat de voorgaande methodische ingang voor het bestuderen van onze moderne samenleving zinvol is, berust ook op een inhoudelijke karakterisering van onze cultuur. Er is wel gezegd dat iemand die tweeduizend jaar geleden in de westerse wereld leefde, naar een willekeurig punt in de tijd tot ongeveer 1800 verplaatst zou kunnen worden, zonder die wereld totaal onbegrijpelijk te vinden. Dat dat niet naar een tijdstip in de laatste tweehonderd jaar zou kunnen, komt doordat de wereld sindsdien te radikaal veranderd is. En de belangrijkste bron van deze verandering, zo wil deze tijdmachine-metafoor zeggen, is de techniek-er is een technologische cultuur ontstaan. ${ }^{6}$

Die technologische cultuur kan worden beschreven via afzonderlijke artefacten: één reactie op de NRC-oproep om een beeld van Nederland in de jaren vijftig te schetsen, volstond met: "de potkachel danst met de kolenkit, de schrob-plank met de asla; de grijze gevlekte pannen proberen een plaats te veroveren tussen het petroliestel en de koffiemolen; de hooikist botst tegen de vleesmolen" ${ }^{7}$ De jaren-90 kunnen we zo beschrijven met het noemen van de autotelefoon, het pincode-pasje, de modem, de magnetron, de glasbak, en de file. Een tweede manier om de technologische cultuur te karakteriseren is te wijzen op het kunstmatige karakter van onze moderne omgeving. Mensen hebben sinds ze van een nomadisch op een agrarisch bestaan overgingen weliswaar altijd getracht hun omgeving te veranderen, "te cultiveren" zeggen we; maar de mate waarin dat doel sinds, zeg, 1800 gerealiseerd wordt, is zonder precedent. De opbrengst van een hectare landbouwgrond is thans ruim zes keer zo groot als die van 100 jaar geleden. ${ }^{8}$ In Nederland is de kans op overstroming van de zeedijken zo'n duizend keer kleiner dan 
voor 1800. Bijna alle besmettelijke ziekten—tot 1950 de belangrijkste doodsoorzaak-zijn nu onder controle. Maar ook: tegen het eind van deze eeuw zal naar verwachting $20 \%$ van alle diersoorten die in 1800 bestonden zijn uitgestorven, en eventuele klimaatveranderingen ten gevolge van het broeikas-effect kunnen de aardse ecologie onvoorspelbaar en ingrijpend veranderen; kanalisatie en ontbossing hebben het debiet $^{9}$ van rivieren dramatisch doen toenemen met alle recente gevolgen van dien voor een kwetsbare technologische cultuur als de onze; en AIDS spot in sommige delen van de wereld op catastrofale wijze met de medische hoogmoed van onze technologische cultuur.

Toen nomaden zich als boeren met de aarde verbonden, had dit ingrijpende culturele gevolgen; even ingrijpend, neem ik aan, zijn nu de gevolgen van het loslaten van de aarde en het ons verbinden met een technologische omgeving. Het is, kortom, ook inhoudelijk de moeite waard onze cultuur te analyseren als een technologische cultuur.

\section{het cultuurbegrip in "technologische cultuur"}

Tot dusver heb ik het vooral gehad over het technologische in "technologische cultuur.". Laat ik nog even stilstaan bij het gehanteerde cultuurbegrip. Ik wil kort de beperkingen laten zien van twee conceptualiseringen van cultuur: de eerste in de tegenstelling natuur-cultuur, de tweede in de tegenstelling struktuurcultuur. Daarna schets ik het cultuur-begrip dat ik zal gebruiken.

Behalve in een tegenstelling tot techniek, zoals hiervoor aangeduid, wordt cultuur ook vaak gedefinieerd in een tegenstelling tot natuur. ${ }^{10}$ De natuur is dan de voedende moeder, die door Baconiaanse wetenschap en moderne technologie wordt onderworpen en uitgebuit. ${ }^{11}$ Cultuur is de beheersing van de natuur; zij is wat het mensen mogelijk maakt van de voedende natuur te leven en in de dreigende natuur te overleven. Vanuit deze tegenstelling zijn de prachtige Amerikaanse "winkel-reservaten" ook te begrijpen als kunstmatige werelden van pure cultuur, de natuur buitengesloten. ${ }^{12}$ Dergelijke kunstmatige werelden hebben een rijke geschiedenis, zij het dat die zich vooral in de literatuur afspeelt-Jules Verne'sTwintig duizend mijlen onder zee, Edward George Bulwer-Lytton'sThe Coming Race, Gabriel Tarde's Under- 
ground Man ${ }^{13}$ Maar zien niet de bezoekers aan een shopping mall in San Francisco een perfecte verbeelding van Tarde's ondergrondse paradijs: "zij openen hun ogen in de meest schitterende en eindeloze kunstgallerijen, in salons die schoner zijn dan die van Versailles, in verheven paleizen waarin alle extremen van weer, regen en wind, kou en verzengende hitte onbekend zijn; waar talloze lampen, als ware zonnen in hun schittering en manen in hun zachtheid, zonder ophouden door de blauwe diepten hun daglicht stralen dat geen nacht kent." ${ }^{14}$ Het is duidelijk dat dergelijke werelden, behalve met literaire, verder alleen met technologische middelen gecreëerd kunnen worden.

Deze constructies van artificiële werelden reproduceren enerzijds de tegenstelling natuur-cultuur, en laten anderzijds zien hoe contingent dat onderscheid is. In die Amerikaanse winkelreservaten is met technologische middelen een nieuwe wereld geschapen; een cultuur die de oude natuur buitensluit en een nieuwe natuur creëert en omvat. Het is juist onze technologische cultuur die de onderscheidingen produceert. ${ }^{15}$ Electriciteit is natuur geworden-als de electriciteit uitvalt (zoals een paar maanden geleden op de Veluwe) is dat een natuurramp, en een natuurramp is pas echt een ramp als de electriciteit uitvalt. Trouwens, aan het bestaan van die natuur op zich wordt ook gemorreld. Ten eerste is veel van wat we thans als natuur beschouwen-zeker in Nederland-eerder ook door mensen gemaakt. Daarmee is elke intuitieve identificatie van wat natuur is twijfelachtig geworden. Zijn bijvoorbeeld de met veel technisch vernuft door Rijkswaterstaat gecreëerde kunstmatige vogel-eilandjes, vlak bij de Oosterscheldekering, natuur of cultuur? ${ }^{16}$ Ten tweede blijken we evenmin te rade te kunnen gaan bij de wetenschap. In de ecologie woedt bijvoorbeeld een controverse tussen twee natuuropvattingen-enerzijds de dominante harmonieuze opvatting die uitgaat van een natuurlijke tendens tot orde, evenwichtige samenhangen tussen subsystemen, en een lange termijn evolutie; en anderzijds een disharmonieuze opvatting die aansluit bij chaostheorieën en waarin de natuur als lapwerk wordt beschouwd, als een mengeling van desorganisatie en zelforganisatie. ${ }^{17}$ De ondubbelzinnigheid waarmee wetenschappelijke eisen en kriteria worden geformuleerd om de ontwikkeling van de 
natuur in bijvoorbeeld een project als de Grensmaas te meten, is dan ook niet geheel onproblematisch. ${ }^{18}$ Op dit moment volstaat de conclusie dat een cultuurbegrip dat zijn stevigheid moet ontlenen aan de tegenstelling tot natuur niet voldoet. ${ }^{19}$

Een tweede manier waarop "cultuur" wordt geconceptualiserd is in de tegenstelling tot struktuur. Vaak figureert cultuur dan als een oude koffer met gewoontes, opvattingen, normen en waarden, die van generatie tot generatie onveranderd meegesleept wordt. Theoretisch is het een restcategorie die slechts te hulp wordt geroepen wanneer de degelijke structurele verklaringen van ekonomische of sociologische aard tekort schieten. ${ }^{20}$ En daarmee heb ik natuurlijk impliciet mijn keuze al laten blijken: wie zou er met zo'n oude koffer op reis willen? Als we technologische cultuur willen bestuderen hebben we een positieve definitie van cultuur nodig en niet één als restcategorie.

Gaan we tenslotte te rade bij moderne antropologen, dan ligt de nadruk op de distributie van gedeelde betekenissen en symbolen en op de processen van hun productie en reproductie. ${ }^{21}$ Cultuur is geen statisch gegeven, maar altijd in ontwikkeling; zij bestaat niet geïsoleerd, maar wordt altijd gedragen door sociaal handelen. Dit cultuur-begrip sluit aan bij het recente onderzoek naar techniekontwikkeling waarover ik later zal spreken. ${ }^{2}$ Daarmee kan cultuur de eenheid van analyse worden. Het is de vloeistof waarin politiek, techniek en sociale controversen oplossen en met elkaar mengen; het is, sterker nog, het spul waaruit techniek, politiek, sociale relaties gemaakt zijn. ${ }^{23}$

\section{technologische cultuur}

Technologische cultuur is dus mijn eenheid van analyse. Zij overstijgt de technologie van onze cultuur en de cultuur van onze techniek. Technologische cultuur is de omgeving waarin wij leven, het vocabulair dat wij spreken, de normen en waarden waarmee wij oordelen en ordenen. ${ }^{24} \mathrm{Zo}$ constateerden Jan en Annie Romein dat "de middeleeuwse bewoners van de Nederlanden (...) met de aanleg der eerste dijken een stap deden die niet alleen ons bodemkarakter, maar ook ons volkskarakter in zeer sterke mate zou bepalen" (Romein, 1934 (1973): 18-19). De chaos in onze technologische cultuur wordt onder controle 
gehouden door in apparatuur geïncorporeerde regels en gewoonten (bijvoorbeeld verkeerslichten, snelheidsbegrenzers op vrachtagens en automatische nachtsloten) en via "gestandaardiseerde" en aan metingen gebonden beslissingen (bijvoorbeeld de ontwerpkriteria voor volkshuisvesting, of de psychologische tests in de zorg voor verstandelijk gehandicapten). De verhouding van burgers tot de nationale gemeenschap is door materiële bestaansvoorwaarden bemiddeldelk individu kan alleen bestaan dankzij de waterzuiveringsinstallaties, transport-infrastrutuur en dijken die door de staat worden beheerd. ${ }^{25}$ De grenzen van onze cultuur zijn moeilijk geografisch af te bakenen, omdat de ruimte van een technologische cultuur afwisselend vergroot, beperkt en vervangen wordt door nieuwe ruimten als de "ether" en "cyberspace."

\section{Problemen}

De technologische cultuur waarin wij leven heeft grote vooruitgang gebracht-ik zeg het zonder ironie. Maar er zijn ook problemen. En dan gaat het niet alleen om beruchte incidentenHiroshima, Vietnam, Bhopal, Chernobyl, de Exxon Valdez. Er zijn structurele problemen die het hart van onze globale technologische cultuur raken: een milieuprobleem, een mondiaal verdelingsprobleem, een vrede- en veiligheids-probleem.

\section{problemen in de technologische cultuur}

Het milieu-probleem kan het best geschetst worden door op globale schaal enkele gegevens te noemen waarover consensus bestaat. Zo hebben de mensen sinds ze met landbouw begonnen zijn, één derde van het bosareaal op aarde vernietigd, en de helft hiervan in de laatste 40 jaar. Het tempo waarmee soorten uitsterven wordt geschat op 10 tot 100 per dag. ${ }^{26}$ Zodra overigens iets precieser en op kleinere schaal het milieuvraagstuk gespecificeerd moet worden, branden de controverses los. ${ }^{27}$ De natuur spreekt, zoals hiervoor al opgemerkt, evenmin ondubbelzinnig tot de ecologen als zij dat doet tot de fysici.

Het mondiale verdelingsprobleem is ondubbelzinniger te karakteriseren. Ongeveer 15 miljoen kinderen sterven elk jaar door 
oorzaken die met honger te maken hebben (Ray, 1995), terwijl in Afrika de voedselproductie per hoofd van de bevolking nog steeds afneemt (Meadows et al., 1992).

Problemen van vrede en veiligheid doen zich in twee heel verschillende vormen voor: de eerste heeft te maken met bedreiging door de natuur; de tweede met bedreiging door mensen. De bedreiging van onze veiligheid door de natuur bestond, dachten we sinds de voltooiing van het Deltaplan vooral in de arme delen van de wereld: gebrek aan voedsel en door natuurrampen verwoeste woonomgevingen. Sinds deze winter weten we dat ook in rijke landen situaties kunnen ontstaan waarbij mensen in hun bestaan worden bedreigd. En juist de aardbeving in Kobe en de rivier-watersnood in Europa ontlenen hun traumatische karakter, denk ik, behalve aan de directe gevolgen vooral aan de dramatische schending van ons geloof in de veiligheid die de moderne technologische cultuur zou bieden. De tweede bedreiging van veiligheid en vrede, door oorlogsgeweld, is sinds het verdwijnen van het IJzeren Gordijn ingrijpend van karakter veranderd. Voor sommige regio's in de wereld geldt een situatie van volledige oor$\log$, terwijl zich zelfs gevallen van genocide voordoen waarbij een vergelijking met de Tweede Wereldoorlog op haar plaats is. En voor een land als Nederland, in een relatief rustige regio, geldt dat sinds de politionele acties in Indonesië nog nooit zoveel soldaten onder direct vijandige omstandigheden paraat geweest zijn als juist nu. Ook de huidige "regionale" conflikten hebben weer alles te maken met ontwikkelingen in de technologische cultuur. Aan wie worden gebruikte wapens van ontbonden legers verkocht, en waar gaan de nieuwe wapens van nog niet op civiele productie overgestapte producenten naar toe? Wat is de invloed van moderne communicatiemiddelen op gevoelens van ethnische identiteit, op natievorming, op internationale onderhandelingen en nationale mobilisatie ? $^{28}$

\section{problemen van democratie}

Ik wil betogen dat deze problemen niet in eerste instantie problemen zijn van de techniek zelf, of van de cultuur, of van de natuur. De fout van Frankenstein, houd ik aankomende CWS-studenten altijd voor, was niet dat hij een onhanteerbare en mon- 
sterachtige techniek creëerde, maar dat hij niet genoeg van haar hield, haar niet voldoende begeleidde; het probleem van rivieroverstromingen is niet alleen een kwestie van teveel regen, maar ook één van besluitvorming rond dijkonderhoud, van kanalisatie en ontbossing. De genoemde problemen zijn vooral een probleem van de democratie van onze technologische cultuur. Hoe geven we vorm aan onze technologische cultuur; hoe verdelen we de lasten en lusten die eraan ontspruiten?

Onze technologische cultuur verkeert in een democratische crisis. Van deze crisis kunnen twee elkaar aanvullende diagnoses gegeven worden. De eerste stoelt op politiek-filosofische analy$\mathrm{ses}^{29}$, de tweede op recent onderzoek naar de rol van techniek in de samenleving.

Benjamin Barber geeft de volgende verklaring voor de schraalheid van de huidige "zwakke democratie" ("thin democracy"). De moderne liberale, representatieve democratie biedt als alternatief voor de jungle de dierentuin: als alternatief voor de oorlog van allen tegen allen, een systeem met kooien, regels, voedertijden en oppassers. Trotse tijgers worden bewonderd om hun individualiteit en eigenzinnigheid, maar tegelijkertijd gekooid om hun dodelijke onbetrouwbaarheid en anti-sociale egoïsme. Burgers worden gezien als atomen van zelf-belang, autonoom en voor hun behoeften-bevrediging niet afhankelijk van een gemeenschap. Politiek speelt in dit perspectief de rol van bedwinger van de individuele instincten: "Legislatures and courts alike deploy penal sanctions and juridical incentives aimed at controlling behavior by manipulating - but not altering or transforming-hedonistic self-interest. People are not made to reformulate private interests in public terms but are encouraged to reformulate public goods in terms of private advantage" (Barber, 1984 (1990): 13). Politiek als de kunst van het dresseren met zweep en suikerklontje. Het huidige "zwakke democratie"-model heeft een aantal problemen. $\mathrm{Er}$ is een obsessie met het zoeken naar een evenwicht tussen absolute vrijheid en absolute macht. De sceptische erkenning van het ontbreken van een absolute oordeelsgrond leidt licht tot verlamming en nihilisme. En in haar moderne vorm van vertegenwoordigende democratie leidt het tot elitisme: "For all the talk about politics in Western democratic regimes, it is hard to 
find in all the daily activities of bureaucratic administration, judicial legislation, executive leadership, and party policy-making anything that resembles citizen engagement in the creation of civic communities and in the forging of public ends. Politics has become what politicians do; what citizens do (when they do anything) is vote for politicians" (Barber, 1984 (1990): 147-148).

De tweede diagnose sluit vooral aan bij het steeds vaker voorkomen van grote publieke controversen over techniek-kernenergie, afvalverwerking en -opslag, dijkverhogingen (of het nalaten ervan), en genetische manipulatie van planten en dieren. Het is duidelijk dat grote technische projecten niet op onvoorwaardelijke steun kunnen rekenen. Dat hebben ze nooit $\operatorname{gekund}^{30}$, maar het leidt nu regelmatiger tot ingrijpende vertrouwensbreuken tussen verschillende groepen in de samenleving. Het zogenaamde NIMBY- (Not In My Back Yard) probleem is hier de meest bekende uiting van. Burgers gooien, zeggen de verontruste politici, de kont tegen de krib en blokkeren alle vooruitgang. Die politici hebben niet helemaal ongelijk: in de V.S. is het inmiddels niet ongebruikelijk dat naast afvalverwerkingsinstallaties en vliegveld-uitbreidingen, ook gevangenissen en klinieken voor drugsverslaafden door NIMBY-actie worden geblokkeerd-de voorziening van elementaire sociale voorzieningen komt zo in gevaar. ${ }^{31}$ De politici hebben wel ongelijk als ze suggeren dat NIMBY-groepen worden gevormd door techno-foben, anti-democraten, en conservatieven. Leden van NIMBY-groepen komen uit alle maatschappelijke lagen, hebben een gevarieerde achtergrond qua opleiding, en bestrijken het hele politieke spectrum. Veel NIMBY-groepen worden geïnspireerd door de milieu-beweging, maar "We're not dope-smoking, hippie environmentalists," citeert Piller (1991: 166) een apotheker in Lexington, Tennessee, die een protest tegen een vuilstortplaats organiseerde: "We're a new breed. We drive pick-up trucks and wear overalls. And we'll be a lot harder to stop."

Dit huidige NIMBY-protest kan gezien worden als een fase in een proces van toenemende maatschappelijke verontrusting over het technologische in onze cultuur zoals dit sinds de jaren ' 60 is gegroeid. ${ }^{32}$ Eind jaren "70 leidde dat tot de ontwikkeling van "technology assessment" (TA) aktiviteiten: het Office of 
Technology Assessment (OTA) van het Amerikaanse Congress werd opgericht in 1973 en de Nederlandse Organisatie van Technologisch Aspektenonderzoek (NOTA—sinds vorig jaar herdoopt tot het Rathenau Instituut) in $1986 .{ }^{33}$

Ik zal in het volgende enkele aspekten van de geschiedenis van TA schetsen, en daarbij vooral de conceptuele ontwikkeling benadrukken. $^{34}$ Deze conceptuele ontwikkeling zal vervolgens blijken te sporen met ontwikkelingen in het recente techniekonderzoek.

Technology Assessment: van "vroege waarschuwing" naar "management van technologie in de samenleving"

\section{ontwikkeling}

Als ik met grote stappen door de geschiedenis van TA loop, kan ik $u$ achtereenvolgens drie verschillende concepties van TA tonen. Het begin van deze ontwikkeling wordt gevormd door vroege waarschuwing $T A$, een reactieve vorm van alarmering voor mogelijke latere negatieve effecten van een zich verder autonoom ontwikkelende technologie. De volgende conceptie is beleidsondersteunende TA, een actieve vorm van TA die vooral gericht is op het suggereren en evalueren van technische alternatieven. De meest recente conceptie is strategische $T A$, een actieve op lange termijn georiënteerde vorm van socio-technische analyse die het verschillende groepen in de samenleving (waaronder de regering en het parlement) beter mogelijk moet maken, met wetenschappelijk-technische ontwikkelingen om te gaan. In de woorden van het recente werkprogramma van het Rathenau Instituut: "TA kan helpen voorkomen dat verstarde structuren en verouderde middelen worden ingezet of dat nieuwe structuren worden ontwikkeld zonder dat eerdere evaringen daarin voldoende worden meegenomen, ermee rekening houdend dat deze ervaringen worden opgedaan in een verschuivende maatschappelijke context" (Rathenau-Instituut, 1994b: 10).

Binnen deze derde, thans dominante TA conceptie onderscheiden Smits en Leyten (1991) drie soorten activiteiten: "awareness TA" om technische en maatschappelijke mogelijkheden op de 
lange termijn nu al bespreekbaar te maken, "strategic TA" om die mogelijkheden te vertalen naar ontwikkelingsplannen voor een middellange termijn, en "constructieve TA" om deze plannen te realiseren in een continue vorm van technologie management met speciale aandacht voor maatschappelijke randvoorwaarden.

\section{conceptuele verschuivingen}

Bezien we de achterliggende ideëen over techniek en maatschappij-over technologische cultuur-in elk van deze drie TAconcepties, dan wordt een duidelijk patroon zichtbaar. De eerste TA initiatieven bouwden voort op de verwachting dat wetenschappelijke kennis een vroege waarschuwing kon geven, en richtinggevend kon zijn bij besluiten over techniekontwikkeling. Wetenschappers speelden dan ook een navenant dominante en exclusieve rol in deze TA. Van de besluitvorming werd aangenomen dat deze georganiseerd was rondom een enkele helder aanwijsbare besluitnemer (parlement, minister, manager), en dat zij verbeterd kon worden door haar meer rationeel te maken. Het resultaat van een dergelijke TA-inspanning was altijd een rapport, waarin de wetenschappelijke feiten voor zich spraken en aldus een solide basis voor politieke besluitvorming vormden.

De huidige TA-conceptie wijkt op belangrijke punten van de vorige af. De beperkingen van wetenschappelijke kennis worden beter onderkend, en in combinatie met een erkenning van het belang van niet-wetenschappelijke bronnen van oordeel en waardering is er nu een meer evenwichtige betrokkenheid van ook gebruikers, producenten, en beleidsmakers naast wetenschappers. Van politieke besluitvorming wordt nu ingezien dat dit een gefragmenteerd en diffuus proces is - het bestaan van slechts één beluitvormer en een rationeel verloop van het beslisproces zijn illusies. Besluiten zijn niet rationeel maar normatief. Het resultaat van TA is thans zelden meer een enkel rapport, maar bijna altijd een rapport plus een voorstel voor (maatschappelijke) discussie.

Deze verschuiving in achterliggende ideëen bij deze TA-concepties blijkt te convergeren met conceptuele ontwikkelingen in het techniekonderzoek, waartoe ik mij nu wend. 


\title{
Techniekonderzoek: kijken naar de cultuur van de technologie
}

\author{
ontwikkeling
}

Ook van het sociologisch-historische onderzoek naar techniekontwikkeling geef ik een korte schets. ${ }^{35}$ Tot de jaren '80 lag de nadruk op onderzoek naar de effecten van technische ontwikkeling op de samenleving. Hoe werkt automatisering door in de werkgelegenheid? Wat zijn de gevolgen van het gebruik van kernenergie? Dit soort onderzoek was niet beperkt tot economische effecten. Bij de gevolgen van kernenergie was bijvoorbeeld ook aandacht voor de kans op nucleaire proliferatie en voor de mogelijke implicaties van alomtegenwoordige politionele bewaking. Ogburn (1933: 159) analyseert bijvoorbeeld de effecten van mechanisering op het rassenvraagstuk in de V.S.: "The mechanical stoker for engines (a) increases the amount of coal going under a boiler, (b) which permits a more powerful locomotive, (c) which increases the length of trains, (d) which makes the distance a passenger carries his baggage greater, (e) which increases the number of porters, (f) which contributes its bit to the status of the Negro."

Sinds de jaren '80 is er meer aandacht voor de ontwikkeling van techniek zelf. Dit betekende impliciet een afscheid van een standaardbeeld van wetenschap en techniek waarin de ontwikkeling van feiten en artefacten alleen wordt bepaald door natuurwetten en technische principes. Volgens dat standaardbeeld viel na een normatief-politiek besluit over welk probleem opgelost moest worden, door niet-ingenieurs verder niets meer over de inhoud van de technische oplossingen te zeggen. Het besluit om Nederland voor de helft in zee te leggen was een politieke keuze; de technische realisatie daarvan met waterkeringen, oeverwerken en gemalen onttrok zich aan sociologisch onderzoek. Er viel alleen nog iets te zeggen als externe factoren-zoals de politiek of de milieubeweging-het werk van de ingenieurs frustreerden; over de inhoud van de techniek zwegen wij, niet-technici, vol eerbied en ontzag.

Dit standaardbeeld bleek niet houdbaar. De ontwikkeling van techniek wordt niet ondubbelzinnig door alleen natuurwetten en technische principes bepaald. Andere factoren, van materiële, 
cognitieve of sociale aard spelen ook een rol. Dat betekent dat er in principe een theorie gemaakt moet kunnen worden over hoe techniek zich ontwikkelt. Verschillende pogingen zijn hiertoe gedaan, en afhankelijk van wat als centrale verklaring van techniekontwikkeling aangenomen werd, zijn er zo materialistische, cognitivistische en sociaal-constructivistische modellen gemaakt.

Ik wil mij nu even tot de sociaal-constructivistische benadering beperken. Uitgangspunt is een beschrijving van technische machines, processen en systemen door de ogen van relevante sociale groepen en niet door de ogen van de onderzoeker of in termen van de enige "echte" of intrinsieke betekenis van die techniek. Dat levert in principe evenzovele machines, technieken, en zelfs werkelijkheden op als er relevante sociale groepen zijn. Als ik nog één keer mijn favoriete voorbeeld mag gebruiken: in plaats van slechts één Hoge Bi (door de ogen van ons, $20^{\mathrm{e}}$ eeuwse terugkijkers) zijn er twee fietsen-de Onveilige Fiets (voor de relevante sociale groep van vrouwen en oudere mannen) en de Macho Fiets (voor de relevante sociale groep van atletische jonge mannen van gegoeden huize). Daarmee is de betekenis-flexibiliteit van de Hoge Bi gedemonstreerd. Er is niet één machine met één ingebakken, vanzelfsprekende identiteit-bepaald door natuurwetten en technische principes. Maar er zijn verschillende machines, met verschillende identiteiten, sommige wel werkend, andere niet werkend-bepaald door sociale interactie-processen in en tussen relevante sociale groepen. De derde stap in de sociaal-constructivistische benadering maakt een tegengestelde beweging. Liet de vorige stap-het demonstreren van betekenisflexibiliteit-zien dat techniek kneedbaar, zacht, sociaal-geconstrueerd is; de derde stap beschrijft hoe de karakteristieke hardheid van techniek ontstaat (en, let wel, nog steeds sociaalgeconstrueerd is). Het concept dat deze stabilisatie en verharding beschrijft is het technisch raam van een relevante sociale groep: de doelen, waarden, normen, theorieën, vaardigheden, vuistregels, en machines die het denken en handelen van leden van die groep bepalen. ${ }^{36}$ De interacties in relevante sociale groepen, beschreven door hun technische ramen, leiden tot stabilisatie van een artefact: er komt een eind aan de betekenisflexibiliteit en de techniek wordt hard. De Hoge Bi is na dat stabilisatie-proces alleen nog 
maar een Onveilige Machine, en wie er toch op rijdt is vermoedelijk nog steeds een macho, maar nu ook een sufferd.

Het sociaal-constructivistische techniekonderzoek van de afgelopen vijftien jaar beschouw ik als een opstap naar waar ik het vanmiddag over heb. Het voorgaande techniekonderzoek richtte zich niet zozeer op de technologische cultuur in de hiervoor aangeduide brede zin, als wel meer beperkt op de cultuur van technologie. Het onderzoek richtte zich op de werkplaatsen en tekenafdelingen van producenten, op het koop- en gebruiksgedrag van consumenten, en op de ontwikkeling van afzonderlijke machines en technische systemen. Dit was enerzijds een beperktere vraagstelling dan die waar ik vanmiddag over spreek. Anderzijds vormt het een conditio sine qua non voor het nu voorgestelde onderzoek naar de moderne technologische cultuur. Als we niet het sociaal-geconstrueerde karakter van techniek onderschrijven, valt er niet op een geïntegreerde manier over techniek en samenleving te spreken, blijft techniek een Fremdkörper, een voortdenderend vliegwiel, een ongeleid projectiel.

\section{conceptuele verschuivingen}

Ook bij het techniekonderzoek van de afgelopen decennia wil ik de conceptuele verschuivingen schetsen die zijn opgetreden in de achterliggende ideeën over de relatie techniek-samenleving. Het vroege techniekonderzoek bouwde voort op de veronderstelling dat er een heldere scheiding is tussen het technische en het sociale. Over die kloof tussen techniek en samenleving ging maar een één-richtingsbruggetje. Maatschappelijke omstandigheden hebben (bedoeld noch onbedoeld) geen enkele invloed op de techniek, die zich autonoom ontwikkelt-volgens een eigen, interne logica. Techniekontwikkeling is als een trein: hij dendert voort; je kunt zijn richting niet veranderen zonder de boel te laten ontsporen; en je kunt hoogstens wanhopig aan de rem gaan hangen of enthousiast de snelheid verhogen. Daartegenover heeft de techniek wel belangrijke effecten op de maatschappij. ${ }^{37} \mathrm{Zij}$ schept of vernietigt werkgelegenheid, zij produceert of reinigt vervuiling, zij verdeelt rijkdom of creëert maatschappelijke ongelijkheid. In dit standaardbeeld heeft techniek een ondubbelzinnige, als het ware "ingebakken" betekenis—of een ma- 
chine goed werkt of niet, is bijvoorbeeld een eigenschap van alleen die machine en onafhankelijk van de context.

Dit standaardbeeld van techniek in de laatste vijftien jaar dus grondig bijgesteld. In plaats van autonoom, zien we techniek als sociaal geconstrueerd. Machines of sociale organisaties-beide worden voortaan geanalyseerd als socio-technische ensembles. Het "werken" en "niet-werken" van een machine is het resultaat van sociale processen, niet (alleen) de bron van sociale verandering. Techniek en samenleving ontwikkelen zich in een vorm van co-evolutie, als twee kanten van één medaille-en vandaar ook de nieuwe eenheid van analyse: technologische cultuur.

Op het kruispunt van techniekonderzoek en technology assessment

De beide geschetste ontwikkelingen -in het TA onderzoek en in het techniekonderzoek-volgen vergelijkbare patronen en convergeren tot een samenhangend beeld van technologische cultuur. Wat gebeurt er op het kruispunt waar zij samenkomen? Ik zie twee elkaar aanvullende programma's. Het eerste is constructieve technology assessment; het tweede benoem ik met "democratisering van de technologische cultuur." Het eerste is een vrij concrete verzameling antwoorden in de vorm van sturingstechnieken; het tweede stelt vragen in de vorm van een breed onderzoeksprogramma. Het eerste kun je aan de EU verkopen; over het tweede kan ik (voorlopig) alleen een oratie houden.

\section{constructieve technology assessment}

De combinatie van recent techniekonderzoek en nieuwe TA-benaderingen is op zich al voldoende voor het eerste programma-een zinvol technologiebeleid in een brede zin van dat woord. Een niet exclusief economisch georiënteerd "nieuw paradigma voor management van technologie in de samenleving" met aandacht voor ook sociale, politieke en culturele aspekten kan daarmee de beperkingen van het gebruikelijke technologiebeleid overstijgen. ${ }^{38}$ Dit programma heeft aandacht voor mogelijke bijdragen aan het 
ontwerpproces door andere sociale groepen dan alleen de producenten; het heterogene karakter van technologie-ontwikkeling wordt in de beschouwingen betrokken; en in plaats van met een simpel lineair stimulus-respons model wordt in termen van "niche-management" over sturing van techniekontwikkeling nagedacht. ${ }^{39}$ Dit programma van constructieve TA vormt weliswaar een cruciaal onderdeel van het tweede-hierna te besprekenprogramma, maar is wel beperkter. De beperking schuilt in de primaire oriëntatie op één bepaalde actor-vaak parlement, regering of een bedrijfsmanagement. Ook het denken in termen van "sturing", "beleid", "regelgeving" duidt op een soms impliciete keuze van een bepaalde voorkeurs-actor; meestal in de rol van promotor of controleur.

democratisering van de technologische cultuur

Het tweede programma, "democratisering van technologische cultuur" combineert de twee convergerende ontwikkelingen in technology assessment en techniekonderzoek met een aantal andere recente ontwikkelingen. Deze zijn, ten eerste, het actie-onderzoek zoals dat vooral in Scandinavië en Nederland in de jaren '70 van de grond is gekomen in samenwerkingsprojecten tussen universiteiten en bijvoorbeeld de vakbeweging of boerenorganisaties. ${ }^{40}$ Ten tweede wordt voortgebouwd op onderzoek naar grote technisch-politieke controversen zoals dat vooral in de V.S. en Engeland heeft plaats gevonden. ${ }^{41}$ En ten derde kan aansluiting gevonden worden bij discussies onder politicologen en politieke filosofen over nieuwe vormen van democratie.

Ik wil hier vier elementen van dit "democratisering van technologische cultuur" programma schetsen. Dat zijn achtereenvolgens: het principieel niet-bestaan van gepriviligeerde groepen, twee soorten macht, twee types hardheid van technologie, en het idee van sterke democratie.

Er zijn geen voorkeursgroepen in techniekontwikkeling. Werd volgens het standaardbeeld van techniek een dergelijke voorkeurspositie ingenomen door de ingenieurs, vanuit een sociaalconstructivistisch perspectief blijken vrouwen een cruciale rol gespeeld te hebben in de ontwikkeling van de fiets (en dan bedoel ik niet vrouwelijke fiets-ingenieurs), managers in de uitvinding van 
de TL-lamp, en octrooirechters in de constructie van plastic. ${ }^{42}$ Denken in termen van sturing of management, zoals in het hiervoor geschetste programma, doet afbreuk aan de radicale implicaties van dit inzicht. Ik wil hiermee drie punten maken-een methodologisch, een empirisch en een politiek. Methodologisch impliceert deze afwijzing van voorkeursgroepen een symmetrische benadering van alle relevante sociale groepen, met eenzelfde conceptuele bril en zonder aannames vooraf over wat hun specifieke belangen, deskundigheden of maatschappelijke posities zijn. Empirisch betekent het dat we voor het begrip van een concrete techniekontwikkeling verder moeten kijken dan de op het eerste gezicht direct betrokken technici, managers en marketing-mensen. Het proces van sociale constructie gaat door, vaak lang nadat de artefacten de fabriek verlaten hebben. In politiek opzicht is de consequentie niet zozeer dat er meer aangrijpingspunten zijn voor sturing-die conclusie wordt ook getrokken binnen het constructieve TA perspectief. Het gaat er vooral om dat er geen principieel argument meer is om aan de ene groep een gewichtiger rol toe te kennen in discussies over techniekontwikkeling dan aan andere groepen. Betogen dat voorkeursgroepen niet bestaan is een statement dat ingrijpt in het politieke debat in de technologische cultuur. Alle relevante sociale groepen zijn gelijk.

Maar, en daarmee kom ik aan het tweede element, zijn sommige groepen niet meer gelijk dan andere; deze meer relevant dan die? Oftewel: speelt macht dan helemaal geen rol? Natuurlijk wel. Maar de manier waarop we zinvol over die macht kunnen praten ligt niet voor het oprapen. Bestaande theorieën besteden nauwelijks aandacht aan de rol van techniek-en voorzover ze dat wel doen, gebeurt het of op een algemeen en abstract niveau ${ }^{43}$, óf op een heel naïeve manier. ${ }^{44}$ We hebben een conceptualisering van macht nodig die, door voort te bouwen op het recente techniekonderzoek, minder naïef is en meer precies rekening houdt met de rol van artefacten en technische systemen en processen.

Naarmate een technisch raam van een relevante sociale groep zich meer stabiliseert, krijgen de daarbij horende artefacten, praktijken, rollen een vastere betekenis. Niet alles is meer mogelijk. Een Hoge Bi is een Onveilige Fiets en je kunt er niet meer de 
blits mee maken. Een dijk is primair een waterkering en geen landschappelijk element (of, zoals tot vorige maand, juist het omgekeerde ${ }^{45}$ ). Die fixatie van betekenissen beperkt mensen in hun handelen, hij oefent macht uit. Deze structuur van gefixeerde betekenissen noem ik een semiotische machtsstructuur. "Semiotisch" omdat het de betekenissen van machines, mensen, handelingen, beelden zijn die macht uitoefenen-doordat ze mogelijkheden scheppen en beperkingen opleggen. De toga die ik draag oefent macht uit—op mij (ik heb ervan afgezien mijn favoriete $\mathrm{OH}$-projector te gebruiken omdat ik mezelf zo niet vrij over het podium zag bewegen), maar ook op u (de woorden die ik uitspreek hebben een zwaardere betekenis dan wanneer ik hier in mijn tuinkleren had gestaan). De toga kan ook min of meer bewust als machtsinstrument ingezet worden: ik kan proberen nog een extra uurtje door te gaan, hopend dat $u$ door de hierarchische betekenis van de toga in bedwang gehouden wordt. Zo oefenen artefacten macht uit: als elementen in een semiotische machtsstructuur. Dit is ook de macht die wordt ervaren als "technisch determinisme"; maar ze kan nu worden begrepen als een resultaat van menselijke interactie in plaats van als een aspekt van een interne logica van de techniek. Ze kan dan ook meer of minder bewust worden gecreëerd: "Fate can be engineered. In that case, we should look at those who choose to invest in large, complex technologies, and consider that they may do so quite deliberately in order to create technological determinism". ${ }^{46}$ Maar die macht heeft haar grenzen: niet iedereen is er even gevoelig voor. Alleen mensen wier handelen wordt geleid door het betreffende technisch raam zullen er de beperkingen van voelen. Liselotte ( 6 jaar), die de toga een soepjurk noemt, zal niet nog een uur blijven zitten. Een treinmachinist beschreef eens de bijna fysieke pijn die hij voelde wanneer hij, na telefonische instructie van de verkeersleiding daartoe, langszaam door een rood licht reed-dat licht oefende een macht op hem uit waar ik, niet opgevoed als treinmachinist, vrijwel ongevoelig voor zou zijn. Dit is het eerste aspect van dit machtsconcept-structureel en semiotisch gekleurd.

Het tweede aspect van dit machtsconcept is interactionistisch gekleurd en meer strategisch van aard. Het technisch raam van 
een relevante sociale groep biedt actoren vele strategieën om artefacten te stabiliseren of te destabiliseren, om coalities met andere groepen aan te gaan of deze juist dwars te zitten. Het betreft hier een voortdurend proces van heterogene acties om vorm te geven aan de technologische cultuur-"micropolitiek" noem ik het [Bijker, 1995 \#5]—en zo een zekere vorm van disciplinering te realiseren. ${ }^{47}$ Deze resulterende disciplinering kan dan weer worden begrepen als een semiotische machtsstructuur door toegenomen stabilisering van een technisch raam. De verschillende interacties gedurende deze plechtigheid geven deze toga de betekenis en de semiotische macht die zij heeft (als ik hiermee op het Vrijthof ga staan, denkt men alleen maar dat mijn horloge vier weken achter loopt); evenzeer doet mijn interactie met $\mathrm{u}$, waarbij ik de toga als didaktisch voorbeeld gebruik, juist afbreuk aan de macht ervan.

Het derde element voor het programma "democratisering van technologische cultuur" wordt gevormd door een conceptie van de hardheid van technologie. Dit is belangrijk omdat zonder een dergelijk idee de slordige lezer van een constructivistische techniekanalyse makkelijk, hoewel ten onrechte, zou kunnen concluderen dat "alles dan wel mogelijk is." (Op dezelfde manier wordt "de markt" ook vaak gezien als grenzen stellend aan de democratie. En ook met die veronderstelde hardheid valt het wel mee: als bijvoorbeeld de economische waarde van de grond had bepaald wat er na de Ramp in 1953 gebeuren moest, dan hadden we een stukje Duitsland gekocht en niet dat stuk Zeeland teruggewonnen voor een veelvoud van de grondprijs. Economische waarde, prijzen, en markten zijn evenzeer sociaal geconstrueerd als machines. Maar nu terug naar die machines.) Voor een bepaalde persoon kan techniek zich op twee manieren als hard manifesteren-ik noem ze respectievelijk "weerbarstig" en "opsluitend." Deze twee soorten hardheid zijn afhankelijk van hoe centraal deze persoon in het betreffende technisch raam zit. Voor iemand die erg centraal zit-een hoge inclusie noem ik dat-heeft de betreffende techniek een grote hardheid in de vorm van opgeslotenheid, omdat er geen ontsnappen aan is: er zijn weliswaar veel mogelijkheden tot differentiatie binnen die techniek, maar het is ondenkbaar het zonder te doen. Voor iemand 
met een lage inclusie heeft techniek een heel ander soort hardheid, een weerbarstigheid: het is een slikken of stikken, geen mogelijkheid tot variatie binnen de techniek maar wel de mogelijkheid om haar helemaal te weigeren. Even een voorbeeld. Stelt $\mathrm{u}$ zich twee mensen voor achter een "personal computer." De eerste heeft een hoge inclusie in het technisch raam van de PC, de tweede een lage. Er gaat iets mis: de printer braakt abacadabra uit. Wat zullen zij doen? Mijn voorspelling is dat het meisje met de hoge inclusie, na een snelle controle van de verbindingssnoeren, met de printerdefinities gaat sleutelen. $\mathrm{Zij}$ komt niet op het idee haar brief met een balpen af te schrijven-ze is, met enige overdrijving gezegd, opgesloten in de techniek van de PC. De jongen met de lage inclusie daarentegen ziet geen uitweg, kan alleen nog nee zeggen tegen deze weerbarstige techniek, en pakt zijn vulpen.

Met deze twee concepten van de hardheid van socio-technische ensembles gewapend, kunnen we nu ook naar het NIMBYverschijnsel kijken. Als een bepaald socio-technisch ensemble (een gifstort in Eijsden of een dijkverhoging langs de Waal) wordt gepresenteerd aan mensen met een lage inclusie in het bijbehorende technisch raam, zal het de tweede soort weerbarstigheid hebben: slikken of stikken. En dat wordt, met een groeiend arsenaal aan micropolitieke middelen nu dus steeds vaker stikken. Alleen als die mensen een hogere inclusie krijgen, krijgt het betreffende project die andere hardheid, die opsluiting en vanzelfsprekendheid. Maar let wel: dat gebeurt alleen bij hogere inclusie, en dus participatie in dat technisch raam. Afkopen met een beetje meepraten zonder daadwerkelijke invloed op de inhoud van agenda, ontwerp en implementatie werkt niet. ${ }^{48}$ En daarmee kom ik aan het laatste en vierde element in mijn discussie van "democratisering van technologische cultuur."

Barber stelt tegenover het zwakke, vertegenwoordigende democratie-model dat ik hiervoor kritisch besprak een model van sterke, participerende democratie: "strong democracy in the participatory mode resolves conflict in the absence of an independent ground through a participatory process of ongoing, proximate self-legislation and the creation of a political community capable of transforming dependent private individuals into free citizens 
and partial and private interests into public goods" (Barber, 1984 (1990): 151). In plaats van te zoeken naar een voor-politieke, onafhankelijke grondslag of een tijdloos, rationeel meesterplan, vertrouwt sterke democratie op participatie in een zich ontwikkelende gemeenschap van burgers die publieke doelen creëert waar deze voordien niet bestonden, en dit doet door middel van eigen aktiviteit. Zulke publieke doelen worden niet geëxtrapoleerd uit absolute premissen, noch ontdekt in al bestaande, maar verborgen, consensus. Ze worden letterlijk door publieke participatie gesmeed uit gemeenschappelijke deliberatie en actie.

Het sterke democratie-model sluit naadloos aan bij de voorgaande elementen die op het sociaal-constructivistische techniekonderzoek gebaseerd zijn. Deze aansluiting geldt filosofisch. Kern van het sterke democratie-model is immers een afzien van een onafhankelijke fundering voor democratische besluitvorming, zoals in het techniekonderzoek wordt afgezien van tijdloze natuurwetten of efficiëntie als leidend principe. Maar de aansluiting geldt ook politiek. Ik heb hiervoor laten zien hoe het constructivistische techniekonderzoek de politieke uitspraak oplevert dat er geen voorkeursgroepen zijn die maatschappelijke doelen bepalen. In het sterke democratie-model worden democratische doelen evenzeer in participatie gecreëerd als machines in interactie worden geconstrueerd. ${ }^{49}$ Het participatieve proces van zelf-wetgeving stoelt op een evenwicht tussen de micropolitieke strategieën van tegengestelde groepen en een naar elkaar luisteren van die groepen. Dit sluit aan bij de hiervoor geconstateerde noodzaak om invloed op agenda, ontwerp en implementatie te delen. In Barber's (1984 (1990): 175) woorden: "'I will listen' means to the strong democrat not that I will scan my adversary's position for weaknesses and potential trade-offs, nor even (as a minimalist might think) that I will tolerantly permit him to say whatever he chooses. It means, rather, 'I will put myself in his place, I will try to understand, I will strain to hear what makes us alike, I will listen for a common rhetoric evocative of a common purpose or a common good."' De centrale rol van taal in interactie onderstreept ook nog eens het constructivistisch karakter van sterke democratie: met taal "we can invent alternative 
futures, create mutual purposes, and construct competing visions of community" (Barber, 1984 (1990): 177).

Hiermee sluit ik mijn bespreking af van het programma "democratisering van de technologische cultuur", de tweede weg die vanaf het kruispunt van TA en techniekonderzoek gevolgd kan worden. Deze bespreking vormde de kern van mijn betoog vandaag.

Wat zijn de implicaties van dit alles? Wat is het antwoord op de vaak zo dodelijke vraag "so, what?" Ik wil kort nog iets zeggen over mogelijke politiek-maatschappelijke implicaties, en daarna over consequenties voor onderzoek en onderwijs.

\section{Politieke implicaties}

Politieke implicaties van het programma "democratisering van technologische cultuur" zal ik op drie manieren bespreken. Eerst is er een algemene conclusie die vooral met het constructivisme en de nadruk op technologische cultuur verbonden is; dan iets over concrete politieke experimenten; en tenslotte over de relevantie van dit soort onderzoek voor politieke vragen.

Het kiezen van "technologische cultuur" als eenheid van analyse is op zich al van politieke betekenis-nieuwe ordeningen van de wereld worden mogelijk, oude hierarchieën uitgehold; nieuwe verbanden gecreëerd, oude oplossingen uitgesloten. De constructivistische benadering geeft dit vervolgens meer concrete vorm. Ten eerste biedt dit programma een tegenwicht tegen de fatalistische technisch-deterministische visie, waarin techniekontwikkeling iets is waarvoor we ons wellicht tijdig kunnen laten waarschuwen, maar waar we niet veel aan kunnen veranderen. Ten tweede biedt het concrete aanknopingspunten voor politiek handelen in een brede zin van dat woord. Het scala aan relevante sociale groepen dat bijdraagt aan de constructie van socio-technische ensembles is veel groter dan volgens het standaardbeeld van techniekontwikkeling; en daarmee is ook het aantal mogelijke aangrijpingspunten voor politieke actie zoveel groter. Ten derde kunnen we nu ook begrijpen waarom het goed is dat van Den Doolaard's "vertrouwen van de gewone mensen in de tovenaars" niet meer zo veel over is. Politici kunnen zich niet meer alleen 
verlaten op wetenschappelijke en technische deskundigen, en burgers willen dat niet meer. Vertrouwen moet gewonnen worden en argumenten moeten gewicht krijgen in sociale interactie. Zoals het kabinet Kok heeft ontdekt: liever draagvlak dan daadkracht.

Dit waren consequenties op een vrij algemeen niveau. Welke concrete aanknopingspunten biedt het programma voor een nieuwe democratische inrichting van onze technologische cultuur? Of is al dat gepraat over sterke democratie slechts wereldvreemde luchtfietserij? In een zojuist afgerond onderzoek voor de Duitse Bundestag hebben wij een inventarisatie gemaakt van de manieren waarop in verschillende hoog-ontwikkelde landen wordt omgesprongen met grote publieke technologische controversen. $^{50}$ Eén van de manieren om de verschillende besluitvormingsmodellen te ordenen, is de dimensie van zwakkesterke democratie (zie tabel). Er worden op dit moment al vormen van publieksparticipatie in de praktijk gebracht die tenminste bepaalde kenmerken van de hiervoor geschetste "sterke democratie" hebben. In het geval van de publieke debatten (Rathenau-Instituut, 1994a) die het Rathenau Instituut in Nederland organiseert is dat bijvoorbeeld het streven naar een principieel "open dialoog" tussen verschillende betrokkenen, en bij consensus conferenties (Agersnap, 1992) en Citizens' Juries (Crosby, 1992) kan daar-althans in principe- een delegatie van macht aan toegevoegd worden.

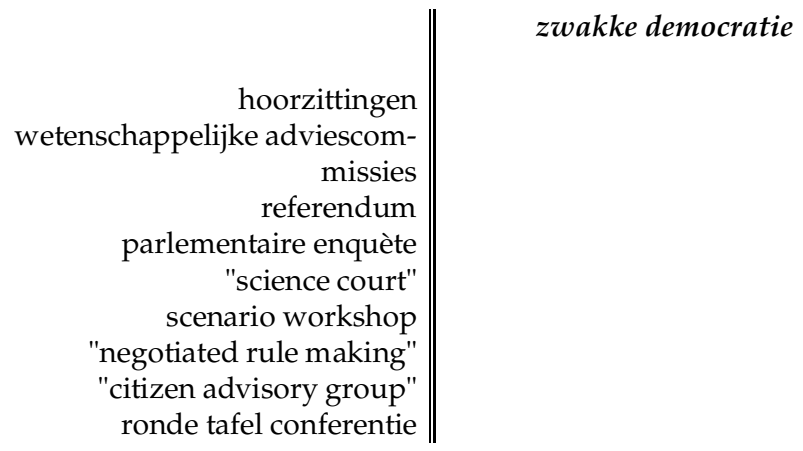




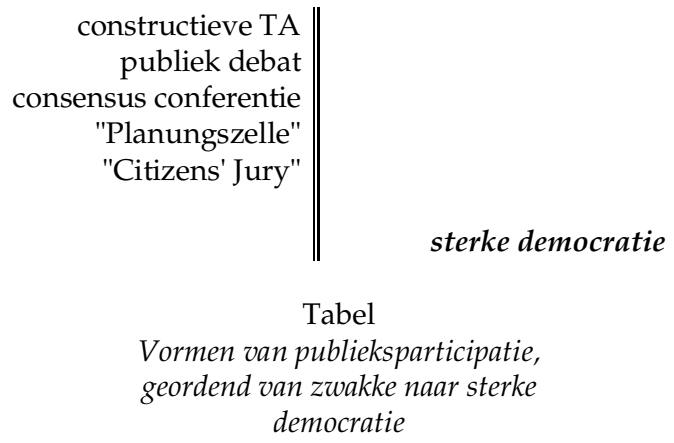

Al deze modellen gaan echter nog uit van een fundamenteel verschil tussen leken en deskundigen; een verschil dat niet strookt met mijn voorstel voor een sterke democratisering van technologische cultuur. In die benadering is er immers geen laatste, onafhankelijke grond voor besluitvorming-dus ook niet "wetenschappelijke kennis." Iedereen is deskundig of leek, afhankelijk van persoonlijke achtergrond en afhankelijk van het aspekt van het probleem waarover besloten wordt. Het is vanuit dit perspectief bemoedigend dat in de adviesgroepen die zijn ingesteld na de commissie-Boertien heel verschillende "deskundigen" deelnemen aan het ontwerpproces van de dijkverbetering: milieu- en bewonersorganisties, provincies, waterschappen, ministeries, en de watertovenaars van Rijkswaterstaat en Waterloopkundig Laboratorium. De instelling van deze adviesgroepen heeft tot gevolg dat belangrijke delen van de bevolking een hoge inclusie krijgen in het technisch raam van het betreffende dijkenplan. De nieuwe dijken krijgen daardoor niet de weerbarstige hardheid die NIMBY-achtige acties en blokkades kan oproepen.

En dan nog een paar algemene opmerkingen over de politieke relevantie van hetgeen ik hier gezegd heb. Die is in directe zin gering. Het voorgestelde programma leidt, meen $i k$, tot meer inzicht in de maatschappelijke ontwikkeling van technologische culturen, in verschijnselen als NIMBY-groepen, en in mogelijkhe- 
den voor participerende besluitvorming. Maar de vertaling naar concrete politieke modellen is een heel andere taak. De grote problemen van de moderne technologische cultuur zoals ik die aan het begin van deze rede heb besproken, vormen dan ook vooral de achterliggende motivatie voor dit werk en niet de concrete puzzels waarvoor een oplossing gevonden zal worden. Vanaf deze leerstoel dien ik immers bij te dragen aan onderzoek en onderwijs in de cultuur- en wetenschapsstudies, en niet aan dat in de bestuurskunde of managementswetenschap. Zo voel ik naast de intellectuele spanning tussen distantie en betrokkenheid ${ }^{51}$, een institutionele spanning tussen bescheidenheid en arrogantie. De bescheidenheid over de concrete bijdragen aan maatschappelijke problemen; en de arrogantie dat ik desondanks hier blijf staan. ${ }^{52}$

\section{Onderzoek}

Diezelfde spanning kleurt ook het onderzoek en onderwijs binnen CWS: wel analyse van centrale problemen in de moderne hoogontwikkelde maatschappij, maar zonder de pretentie van het geven van directe antwoorden.

Vandaag heb ik hier één van de mogelijke onderzoekslijnen binnen CWS uitgewerkt. Deze bestaat in het uitbreiden van het moderne techniekonderzoek met een expliciete aandacht voor democratie in de technologische cultuur. De kracht van dat recente techniekonderzoek is de combinatie van empirisch casusonderzoek en expliciet-theoretische inzet. Ik ben ervan overtuigd dat die empirische verankering in gedetailleerd casus-onderzoek noodzakelijk blijft. Het is niet alleen een manier om de wereld te beschrijven, als in de woorden van William Blake:

To see a world in a Grain of Sand,

And a Heaven in a Wild Flower,

Hold Infinity in the palm of your hand,

And Eternity in an hour.

Het is ook een manier om deskundigheid op te bouwen die van belang is in de interacties met andere betrokkenen, bijvoorbeeld als het gaat om aktieve participatie in politieke discussies. Zoals de milieubeweging geloofwaardig aan tafel kan zitten met wa- 
tertovenaars en plaatselijke overheden doordat ze zich een zekere inclusie in het technisch raam van het dijkbeheer verworven heeft, zo moet een onderzoeker van technologische cultuur ook die minimale inclusie in een relevant technisch raam hebben om mee te kunnen praten.

Tegelijk is duidelijk dat dit onderzoek alleen uitgevoerd kan worden in de soort multi-disciplinaire omgeving die ons CWS-instituut biedt. Empirisch-sociologisch onderzoek is niet voldoende-historische, filosofische en tekstuele analyses zijn even onmisbaar. Een project als Mines et Mineurs, Mijnen en Mijnwerkers, is hiervan een goed vorbeeld. Hierin wordt, bovendien in een internationale samenwerking met onderzoekers van de universiteiten in Aachen, Diepenbeek en Liège, vanuit historische, sociologische, en letterkundige perspectieven de (mijn-)technologische cultuur van deze internationale regio in kaart gebracht.

\section{Onderwijs}

Wat betekent dit alles voor CWS, dat geen marktgerichte beroepsopleiding is, maar een wetenschappelijke studie die reflecteert op problemen in de moderne maatschappij zonder zich in een ivoren toren op te sluiten? De grote uitdaging van CWS als opleiding is, zodanig onderwijs te bieden dat studenten na een heel brede inleiding in de eerste twee jaar toch in de twee laatste jaren een zodange diepgang kunnen ontwikkelen dat zij bijvoorbeeld geschikt zijn voor een AIO-plaats, of zelfstandig een beleidsondersteunende functie kunnen vervullen. Ik denk dat wij-of beter gezegd, de studenten-daar op dit moment in veel gevallen goed in lijken te slagen. ${ }^{53}$ Voor een deel moet dit gerealiseerd worden door de organisatie van het onderwijs: bij CWS zijn dat de afstudeertracé's die deze diepgang mogelijk maken. Maar voor een deel is het ook verbonden met een stijl van onderwijs en onderzoek.

Onderzoek en onderwijs zijn nauw met elkaar verbonden in een universitaire opleiding als de onze. Dat geldt niet alleen voor de onderwerpen, de theorieën, en de boeken. Het geldt misschien nog wel meer voor de stijl van vragen stellen, van dingen onderzoekbaar maken, van werken. Ik heb u daarom vandaag 
willen laten zien hoe heel brede vragen zoals over de democratisering van technologische cultuur onderzoekbaar gemaakt kunnen worden. De pretentie is dan niet, zoals gezegd, dat daarmee die vragen in al hun breedte worden beantwoord, maar wel dat een nieuw perspectief wordt geboden, en een originele bijdrage aan het maatschappelijk debat en de ontwikkeling van wetenschappelijke kennis.

\section{Geachte toehoorders,}

Het College van Bestuur van de Rijksuniversiteit Limburg en het bestuur van de Faculteit der Cultuurwetenschappen dank ik voor het vertrouwen dat zij door deze benoeming in mij hebben getoond.

Collega's van de Faculteit der Cultuurwetenschappen, vrienden en vriendinnen, het is een groot voorrecht met jullie samen te mogen werken. Het is nog steeds een heel gevecht om in een zo jonge faculteit onderzoek en onderwijs van hoge kwaliteit vorm te geven; bestuurlijk zijn we wel vergeleken met een emmer palingen, maar de intellectuele stimulans is groot en ik ben ervan overtuigd dat dat in de toekomst in ons onderwijs en onderzoek zichtbaar zal blijven.

Tegenover collega's van de onderzoeksinstuten MERIT en IRIC en van de andere faculteiten van deze universiteit spreek ik de hoop uit dat de al bestaande samenwerking zal worden uitgebreid. Voor een leerstoel Techniek \& Samenleving, voor een programma "democratisering van technologische cultuur, voor een opleiding Cultuur- en wetenschapsstudies is de elders in de universiteit aanwezige expertise heel waardevol.

Als ik mij tot de CWS-studenten en de AIO's van de onderzoeksschool WTMC richt, dan is dat in de overtuiging dat $u$ degenen bent voor wie dit alles in meest directe zin bedoeld was. Ik hoop een bijdrage te kunnen leveren aan uw wetenschappelijke ontwikkeling, hoe gevarieerd $u$ ook geïnteresseerd moge zijn in de democratisering van technologische cultuur. Dit zal ik dan doen in het besef dat het uiteindelijk de onderwijzer is, die het meest leert. 
Het is gebruikelijk dat men in een inaugurele rede dank betuigt aan zijn intellectuele erflaters. Die lijst van namen is in mijn geval misschien wel langer dan de rede zelf-de kring is te groot. Ik zie daarom af van het afzonderlijk noemen van al deze collega's en vrienden en beperk me tot een collectief dankwoord.

Tot slot maak ik een omgekeerde beweging en trek de cirkel heel nauw om mij heen. Vader Eco, mijn verwijzing naar de watertovenaars en naar Den Doolaard's boek waarin jouw voorganger de hoofdrol speelt was ook bedoeld als een teken van waardering en dank voor wat je voor mij betekend hebt en nog steeds betekent-niet in de eerste plaats, maar wel óók als onderwijzer en onderzoeker.

Tonny, Sanne, Else en Liselotte: ik weet niet goed wat ik tegen jullie moet zeggen. Alle positieve cliché's zijn op jullie van toepassing, dus die zal ik iedereen besparen. Het belangrijkste is dat jullie, gewoon door er te zijn, mij permanent herinneren aan wat, naast alle gepraat over democatisering en technologische cultuur, echt belangrijk in het leven is.

Deze rede draag ik op aan de herinnering van iemand die er niet meer is—aan mijn moeder, Greetje Bijker-Jellema.

Ik heb gezegd. 


\section{Noten}

* Voor het scherper maken van de argumentatie in deze rede heb ik veel baat gehad bij een kritische lezing door Karin Bijsterveld en Rein de Wilde.

${ }^{1}$ Interview, geciteerd door Leydesdorff (1993: 97).

2 Zie voor een schets van deze geschiedenis vanuit het perspectief van het moderne techniekonderzoek Bijker (1993).

${ }^{3}$ Berend Bonkelaar, aannemer, geciteerd door Den Doolaard (1948: 475).

${ }^{4}$ Deze opsomming verwijst naar de vijf (deels nog in voorbereiding zijnde) afstudeertracé's van de opleiding Cultuuren Wetenschapsstudies (CWS) van de Faculteit der Cultuurwetenschappen, Rijksuniversiteit Limburg: (1) natuur en milieu, (2) technologische cultuur, (3) kunst en cultuur, (4) visuele cultuur, (5) politieke cultuur.

${ }^{5} \mathrm{Om}$ greep te krijgen op het complexe karakter van de moderne samenleving is een systeemperspectief zoals uitgewerkt door Luhmann (1990) mijns inziens een minder effectieve onderzoeksbenadering dan wat in het moderne techniekonderzoek wordt aangeduid met de "naadloos weefsel" metafoor; zie voor dat laatste: Bijker (1995a).

${ }^{6}$ In het Nederlands kan er zinvol onderscheid gemaakt worden tussen "techniek" en "technologie." Het eerste duidt dan op de apparaten, processen, systemen-de combinatie van "hardware" en "software" waarmee mensen hun omgeving veranderen. "Technologie" wordt dan veelal voor twee andere betekenissen gereserveerd: (1) kennis van de techniek, technische wetenschap; en (2) complexen en netwerken van verschillende (moderne) technieken. Het is vooral de laatste betekenis die aan de basis ligt van de term "technologische cultuur." Steeds meer wordt overigens "technologie" voor alle betekenissen gebruikt; vermoedelijk onder invloed van het Engels. Zie ook Achterhuis (1992).

${ }^{7}$ G.M.Doeleman-Fischer, geciteerd door Folkert Jensma, "Het 
collectief geheugen. Geuren van gisteren, verloren voorwerpen en geluiden; een lezersinventarisatie", NRC Handelsblad, 24-12-1994.

${ }^{8}$ Dit getal geldt met name voor granen. Ik dank Eugène à Campo voor het maken van deze schatting.

${ }^{9}$ De hoeveelheid water (in $\mathrm{m}^{3}$ ) die per seconde, op een bepaalde plaats, door een rivier stroomt.

${ }^{10}$ In Huizinga's (1935 (1963): 23-24) woorden: "Cultuur betekent beheersen van natuur. Cultuur is aanwezig van het ogenblik af, dat de mens heeft ervaren, hoe de hand, met de ruwe stenen beitel gewapend, dingen vermag, die zonder deze buiten zijn bereik lagen. Hij heeft zich de natuur dienstbaar gemaakt. Hij beheerst de natuur, de vijandige en de schenkende. Hij heeft gereedschap verworven, hij is homo faber geworden."

${ }^{11}$ Een welsprekende woordvoerster van deze visie is Merchant (1980). Zie ook de bundel Machina ex Dea met feministische perspectieven op techniek en samenleving (Rothschild, 1983), en Donna Haraway's (1991) werk. Een mooie feministische interpretatie van Mozart's Die Zauberflöte, die ik in 1991 in Wenen zag, trok dezelfde scheidslijnen: het rijk van de Koningin van de Nacht symboliseerde het natuurlijke, organische en vrouwelijke; Sarastro's priesterrijk vertegenwoordigde de cultuur met "ein straff durchstrukturiertes System von Reglementierungen (...), eine Bastion der Vernunft im Kampf gegen das organische Wachsen." Als het slotkoor zingt "Es siegte die Stärke", is het vrouwelijke door het mannelijke overwonnen. Olivier Tambosi, die de inscenering maakte, besluit in het begeleidende programmaboekje: "Für uns repräsentiert dieser Kampf zwischen männlichem und weiblichem Prizip zugleich den Kampf zwischen ungehindert sich entfaltender Natur und ihrer Beschneidung, ja sogar Zerstörung durch rationalistisches Fortschrittsdenken."

${ }^{12}$ Nederland's bekendste voorbeeld Hoog-Catherijne is typisch Nederlands in zijn treurige truttigheid. Tegelijk is het daarom een juweel van een onderzoeksobject: Nederlandse technologische cultuur op aquarium schaal.

${ }^{13}$ Het prachtige boek Notes on the Underground van Rosalind Williams (1990) beschrijft deze geschiedenis, waarbij haar ingang 
vooral onderwerelden zijn-zowel in metaforische (bijvoorbeeld Gabriel Grub's ondergrondse reis in Dickens' Pickwick Papers, en Jean Valjean's afdaling in de Parijse riolen in Victor Hugo's Les Misérables) als in materiële zin (mijnen, tunnels).

${ }^{14}$ Tarde, geciteerd door Williams (1990: 103); mijn vertaling.

${ }^{15}$ Zie ook het themanummer van Kennis \& Methode onder redactie van Rein de Wilde en Annemarie Mol (1991).

${ }^{16}$ De videofilm "Boetseren met land en water" (Filmproductiebedrijf Van den Ende c.v.) beschrijft, met aanstekelijk enthousiasme en zonder ironie, hoe de waterstaatingenieurs na de maakbaarheid van de geografie nu ook de maakbaarheid van de natuur hebben ontdekt.

${ }_{17}$ Zie Korthals (1994)voor een korte schets van deze controverse en de negatieve gevolgen voor de pretenties van ecologen (Korthals noemt ze "ecocraten") ten aanzien van objectieve wetenschappelijke gegevens over de natuur. Het zal diegenen die het moderne wetenschapsonderzoek kennen overigens niet verbazen dat ecologen evenmin in staat zijn een waardevrij beeld van de macroscopische natuur te geven, als fysici dat kunnen van bijvoorbeeld de subatomaire natuur.

${ }^{18}$ Zie het besluit "Richtlijnen voor het milieu-effectrapport Natuurontwikkelingsplan Grensmaas", Gedeputeerde Staten van Limburg, 5 juli 1994.

${ }_{19}$ Naast de onderscheidingen natuur-cultuur en cultuurtechniek is ook het onderscheid natuur-techniek ondergraven. En voor voorbeelden van cyborgs hoeven we ons niet tot de manifesten van Haraway (1991) te beperken, maar biedt de bioscoop (met bijvoorbeeld films als Terminator I-II en Bladerunner) of het weiland tussen Oost-Maarland en Eijsden ook veel moois te zien. De dikbil runderen bij Oost-Maarland lijken dieren, die zich voortplanten en niet gemaakt worden door mensen; maar dat zijn ze niet: hun kalveren zijn meestal zo groot dat ze niet zonder keizersnede-techniek ter wereld kunnen komendeze "artefacten" kunnen zichzelf niet voortplanten.

${ }^{20}$ In economisch onderzoek is er op deze manier een toenemende aandacht voor cultuur, dat daarmee de rol van technologie als "residual" in de neo-klassieke economie 
overgenomen lijkt te hebben. De Spaanse Foundation for Technology vraagt zich bijvoorbeeld af of "technological culture" gemeten kan worden en of bedrijven er dan beleidsbeslissingen zoals investeringsstrategieën op kunnen baseren.

${ }^{21}$ Een typische omschrijving van "cultuur" door een antropoloog is "a group's shared set of meanings, its implicit and explicit messages encoded in social action" (Traweek, 1988). Hannerz benadrukt een "distributief model van cultuur", waarin een meer expliciete relatie tussen het culturele en het sociale mogelijk is. Dit idee van een relatie tussen cultuur en sociale struktuur "is quite far from that old and simplistic one where the somehow noncultural creates differentiation, and often threatens with conflict and disintegration, while shared culture, whether through consensus or hegemony, unites. Culture is distributed, and includes understandings of distributions. Social structure is based in part on cultural distinctions, in part on distributions of other characteristics; these characteristics are drawn into culture by being meaningful, but stand outside it insofar as the meaning is not wholly arbitrary. And the distinctions and the attributions of meaning on which social structure draws. of course, also entails distributions" (Hannerz, 1992: 15).

${ }^{22}$ Escobar's (1994) gedetailleerd uitgewerkte pleidooi voor een antropologie van technologische cultuur (mijn woorden) is een goede indicatie voor het enthousiasme onder antropologen voor "conceptuele samenwerking" met het recente techniekonderzoek; in de woorden van Hess (1994: 223): "In just a few short years, studies of science and technology within American anthropology have gone from a somewhat backwater status to something of a fad." Zie ook de betreffende sectie in het monumentale Handbook of Science and Technology Studies (Jasanoff, Markle, Petersen, \& Pinch, 1995).

${ }^{23}$ Michiel Schwarz en Michael Thompson (1990) baseren hun discussies van politiek, technologie en sociale keuze op een cultuurtheorie die uitgaat van eenzelfde type cultuurbegrip. Hun uitwerking via de group-grid theorie van Mary Douglas volg ik echter niet.

${ }^{24}$ Vergelijk ook de manier waarop Michiel Schwarz het project 
"De Technologische Cultuur" in De Balie, Amsterdam, heeft vormgegeven (Schwarz, 1994).

${ }^{25}$ Nauta (1995) benadrukt dat deze materiële bemiddeling niet alleen geldt voor uitkeringstrekkers, wat misschien een voor de hand liggende gedachte is wanneer over "collectieve voorzieningen" wordt gesproken.

${ }^{26}$ Zie bijvoorbeeld Meadows (1992). Ik dank Ger Wackers voor zijn hulp bij dit punt.

${ }^{27}$ Zie ook Korthals (1994).

${ }^{28}$ Ik hoorde in de Verenigde Staten dat zeer verspreid levende ethnische minderheidsgroepen via een electronisch bulletin board de laatste jaren een duidelijker identiteit hebben opgebouwd. Die groepen zelf zullen dat als positief ervaren. Ook vanuit een liberaal, multicultureel perspectief op de samenleving is er niets mee mis. Maar anderzijds lijkt etnisch zelfbewustzijn ook een bron van conflicten te kunnen vormen.

${ }^{29}$ In het volgende zal ik vooral aansluiten bij Amerikaanse discussies; zie voor analoge conclusies langs meer "continentaalEuropese" lijnen ook Beck (1993).

${ }^{30}$ Zie bijvoorbeeld kritisch werk van een auteur als Lewis Mumford (1963; Mumford, 1970).

${ }^{31}$ Ook dit is op zich trouwens niets nieuws. Rosenberg (1987) beschrijft hoe men in de $19^{\mathrm{e}}$ eeuw door brandstichting de vestiging van een ziekenhuis probeerde tegen te houden. In die tijd liet de gegoede burgerij zich thuis verplegen en ziekenhuizen waren typische armen-voorzieningen. Evenmin is het beperkt tot de V.S.: Maastricht heeft ook zo haar recente geschiedenis van protesten tegen drugsverslaafden-opvang.

${ }^{32}$ Voorafgaand aan deze brede maatschappelijke onrust waren er al groepen van kritische wetenschappers en ingenieurs geweest die sinds de Tweede Wereldoorlog regelmatig een maatschappelijk debat over ontwikkelingen zoals kernbewapening, kernenergie en zelfs de ontwerphoogte van dijken aanzwengelden. Zie Molenaar's (1994) studie van het Verbond van Wetenschappelijke Onderzoekers voor de Nederlandse geschiedenis van deze beweging.

${ }^{33}$ Ondanks mijn afkeer van het gebruik van Engelse woorden 
in een Nederlandse tekst, blijf ik het ingeburgerde "technology assessment" gebruiken in plaats van het nog vreselijker "technische aspektenonderzoek."

${ }^{34}$ Zie Smits en Leyten (1991) voor een uitgebreid internationaal historisch en conceptueel overzicht van TA-aktiviteiten in de Verenigde Staten, Zweden, West-Duitsland, het Verenigd Koninkrijk, Frankrijk en Nederland.

${ }^{35}$ Zie voor een uitgebreider overzicht Bijker (1995a).

${ }^{36}$ Het concept "technological frame" is vergelijkbaar met Kuhn's paradigma. Het cruciale verschil is dat het ook van toepassing is op andere relevante sociale groepen dan technici: ook het denken en interacteren van milieuactivisten, dijkgraven en provinciebestuuurders kan worden beschreven door hun technisch raam (Bijker, 1995a).

${ }^{37}$ Deze combinatie van autonomie van techniekontwikkeling en maatschappelijke bepaaldheid door de techniek wordt vaak aangeduid met "technisch determinisme." In deze vroege-zeg, "pre-constructivistische"-zin vormt technisch determinisme een belemmering voor een vruchtbare analyse van technologische cultuur. Voorzover het technisch-determinisme een conceptualisering is van de hardheid van techniek, is het natuurlijk wel een belangrijk onderzoeksthema. In mijn beschrijving van het sociaal-constructivisme komt dit in de derde fase aan bod. Zie ook (Smith \& Marx, 1994).

${ }^{38}$ De term "management van technologie in de samenleving" verwijst naar de recente bundel over constructieve TA van Arie Rip, Tom Misa en Johan Schot (1995).

${ }^{9}$ Zie ook het artikel van Schot (1992) met een toepassing van constructieve TA op de casus van milieutechniek.

${ }^{40}$ Deze traditie heeft meer praktijkervaring dan academische publicaties opgeleverd. Een gunstige uitzondering is het werk van auteurs als (Noble, 1977, 1979) en Mathews(Mathews, 1989). Zie ook de korte discussie tussen Hull (1994) en Bijker.

${ }^{41}$ De "grand old lady" van dit onderzoek is Dorothy Nelkin (1992). Andere belangrijke auteurs zijn Wynne (1982; Wynne, 1987, 1995), en Sclove (1993; Sclove, 1983).

${ }^{42}$ Zie voor een nadere uitwerking van elk van deze casus: 
Bijker (1995c).

${ }^{43}$ Zie bijvoorbeeld Beck (1986; Beck, 1993) en Giddens (1984).

${ }^{44}$ Dit geldt bijvoorbeeld ook voor een politiek-filosoof als Barber (1984 (1990)). Net als veel van de recent tot het techniekonderzoek bekeerde antropologen, denkt hij ten eerste alleen aan de moderne electronische informatie- en communicatietechnologie. En ten tweede heeft hij ook daar dan naïeve ideëen over: zijn sterke democratie (zie hierna) zou middels de electronische gemeente-vergadering tot stand kunnen komen. Het is alsof we de optimistische verhalen van volksverheffing en sociale integratie bij de invoering van de televisie weer horen...

${ }^{45}$ Vóór de recente waterdreiging was het veel vanzelfsprekender om over een zeedijk te schrijven: "Kortom, een dijk is méér dan alleen een veilige zeewering. Op een rijk begroeide dijk kunnen we genieten van vogels en krabbetjes die er voedsel zoeken, van wieren die meegolven met het water." (Brochure "Dijktuin" van de Dienst Getijdewateren, Rijkswaterstaat, Ministerie van Verkeer en Waterstaat).

${ }^{46}$ Williams (1994: 225); cursief in origineel.

${ }^{47}$ De term "disciplinering" verwijst naar Foucault (1979). Zie voor voorbeelden uit de gebouwde omgeving ook Markus (1993).

${ }^{48}$ De WRR (1994: 54) komt in een recent rapport tot eenzelfde diagnose: "Kenmerkend voor de besluitvorming ten aanzien van grote projecten is het relatief grote gewicht daarin van de technische component. (...) In dit verband is ook van belang dat de technische fasen doorgaans voorafgaan aan de politieke en maatschappelijke besluitvorming. (...) Dan kunnen de technische en politiek-maatschappelijke componenten tegen elkaar worden gepolariseerd." Ook de therapie is vergelijkbaar: "Het bevorderen van een interactieve besluitvorming sluit aan bij het doelzoekend karakter van veel grote projecten en de noodzaak een veelheid aan doelen te dienen, doordat actoren met uiteenlopende doelstellingen worden verenigd op één middel, het project" (WRR, 1994: 65). De nieuwe Tracé-wet (Staatsblad 1993 582, 16 september 1993) en NIMBY-wet (Staatsblad 28, 22 december 1993) voldoen hier niet aan. 
${ }^{49}$ Barber realiseert zich dit niet, hetgeen niet vreemd is voor een boek dat in 1984 werd geschreven. Hij getroost zich veel moeite om het verschil tussen politieke kennis en wetenschappelijke kennis te bespreken en hanteert daarbij het "standaard-beeld" van wetenschap. Het beeld dat hij van politieke kennis geeft komt heel dicht bij het moderne constructivistische wetenschapsbeeld: "Political knowledge in a strong democracy also turns out to be artificial rather than representational. the strong democrat is more Kantian than Platonist in his view of conduct as created. Politics condemns us to a freedom from which pure reason cannot extricate us" (Barber, 1984 (1990): 170). Zie voor het constructivistische wetenschapsbeeld verder Collins (1985) en Latour (1987).

${ }^{50}$ Het onderzoek "Understanding the Politics of Technology. A Comparative International Study of Technological Controversies and Technology Acceptance" werd uitgevoerd door Wiebe E. Bijker, Anthony Arundel en Jessica Mesman, met assistentie van Carla Hillekens en Anique Hommels. De volgende landen werden in de vergelijking betrokken: Frankrijk, Groot-Brittannië, Japan (beperkt), Nederland, en de Verenigde Staten.

${ }^{51}$ Vergelijk de bundel van Nauta (1992).

${ }^{52}$ Ik bedoel hier niet precies de arrogantie die Cohen (1995: 2829) beschrijft als hij een denkbeeldige academicus de even denkbeeldige burgers laat toespreken: "Jullie snappen er helemaal niets van, neem dat nou maar van ons aan, want wij, hoogopgeleide leden van de universitaire gemeenschap, wij weten wèl hoe het zit. En wij, leden van de universitaire gemeenschap, goedgebekt als wij zijn, wij willen het nog wel eens uitleggen, en wij doen dat mooi, wij doen dat gelikt, wij wentelen ons in ons gelijk: wij laten ons gelijk aldus met de nodige arrogantie zien." De in mijn ogen noodzakelijke arrogantie om door te gaan met fundamenteel onderzoek ondanks dat daar geen direct toepasbare resultaten uit voortkomen, ontslaat niet van de plicht hierover zo goed mogelijk verslag te doen en nietuniversitaire burgers te betrekken bij een discussie over de zin van dit soort onderzoek. Inaugurele redes zouden daar een goede gelegenheid voor kunnen zijn, maar geven de zaal gewoonlijk 
weinig gelegenheid tot weerwoord.

${ }^{53}$ Ik zeg "lijken" omdat de eerste CWS-studenten nog moeten afstuderen. Mijn optimistische indruk is gebaseerd op wat doctoraal-studenten op dit moment laten zien in stages, prescripties en scriptie-onderzoek. 


\section{Literatuur}

Hans Achterhuis (Ed.). (1992). De maat van de techniek. Baarn: Ambo bv.

Torben Agersnap. (1992). Consensus Conferences for Technological Assessment. Paper presented at the Technology and Democracy, Copenhagen.

Benjamin R. Barber. (1984 (1990)). Strong Democracy. Participatory Politics for a New Age. Berkeley: University of California Press.

Ulrich Beck. (1986). Risikogesellschaft: Auf dem Weg in eine andere Moderne. Frankfurt am Main: Suhrkamp Verlag.

Ulrich Beck. (1993). Die Erfindung des Politischen. Zu einer Theorie reflexiver Modernisierung. Frankfurt am Main: Suhrkamp Verlag.

Wiebe E. Bijker. (1993). Dutch, Dikes and Democracy. An Argument against democratic, authoritarian, and neutral technologies. Lyngby: Technical University of Denmark, Unit of Technology Assessment.

Wiebe E. Bijker. (1995a). Sociohistorical Technology Studies. In S. Jasanoff \& G. E. Markle \& J. C. Petersen \& T. Pinch (Eds.), Handbook of Science and Technology Studies (pp. 229-256). London: Sage.

Wiebe E. Bijker. (1995c). Of Bicycles, Bakelites and Bulbs. Toward a Theory of Sociotechnical Change. Cambridge, MA: MIT Press.

Samuel Butler. (1872 (1983)). Erewhon ( 9th ed.). Harmondsworth, Middlesex: Penguin Books Ltd.

M.J. Cohen. (1995). Professoren en de politiek. Unpublished Diesrede Rijksuniversiteit Limburg, 13 januari 1995, Maastricht.

H.M. Collins. (1985). Changing Order: Replication and Induction in Scientific Practice. London: Sage.

Ned Crosby. (1992). A Solution for Difficult Environmental Questions (Revised Version). Paper presented at the Novel 
Approaches to Participation in Environmental Conflicts, Humboldt.

A. den Doolaard. (1948). Het verjaagde water. Amsterdam: Em. Querido's Uitgeversmaatschappij.

Arturo Escobar. (1994). Welcome to Cyberia. Notes on the Anthropology of Cyberculture. Current Anthropology, 35(3), 211-231.

Michel Foucault. (1979). Discipline and Punish: The Birth of the Prison (A. Sheridan, Trans.). New York: Vintage Books.

Anthony Giddens. (1984). The Constitution of Society. Outline of the Theory of Structuration. Cambridge: Polity Press.

Ulf Hannerz. (1992). Cultural Complexity. Studies in the Social Organization of Meaning. New York: Columbia University Press.

Donna J. Haraway. (1991). Simians, Cyborgs, and Women: The Reinvention of Nature. New York: Routledge.

David Hess. (1994). Comment to Escobar's "Welcome to Cyberia". Current Anthropology, 35(3), 223-224.

J. Huizinga. (1935 (1963)). In de schaduwen van morgen. Een diagnose van het geestelijk lijden van onze tijd (9th ed.). Haarlem: H.D. Tjeenk Willink \& zoon N.V.

Richard Hull. (1994). The (Re)Turn to History: A Comment on Wiebe E. Bijker, "Do Not Despair: There is Life After Constructivism". Science, Technology, E Human Values, 19(2), 242-244.

Sheila Jasanoff, Gerald E. Markle, James C. Petersen, \& Trevor Pinch (Eds.). (1995). Handbook of Science and Technology Studies. London: Sage.

Michiel Korthals. (1994). Duurzaamheid en Democratie. Sociaalfilosofische beschouwingen over milieubeleid, wetenschap en technologie. Amsterdam: Boom.

Bruno Latour. (1987). Science in Action: How to Follow Scientists and Engineers Through Society. Cambridge: Harvard University Press.

Selma Leydesdorff. (1993). Het water en de herinnering. De Zeeuwse watersnoodramp 1953-1993. Amsterdam: Meulenhoff. Niklas Luhmann. (1990). Die Wissenschaft der Gesellschaft. Frankfurt am Main: Suhrkamp Verlag. 
Thomas A. Markus. (1993). Buildings \& Power. Freedom \& Control in the Origin of Modern Building Types. London: Routledge.

John Mathews. (1989). Age of Democracy. The Politics of PostFordism. Oxford: Oxford University Press.

Donella H. Meadows, Dennis L. Meadows, \& Jørgen Randers. (1992). De grenzen voorbij. Een wereldwijde catastrofe of een duurzame wereld. Utrecht: Spectrum/Aula.

Carolyn Merchant. (1980). The Death of Nature: Women, Ecology and the Scientific Revolution. New York: Harper and Row.

Leo Molenaar. (1994). 'Wij kunnen het niet langer aan de politici overlaten...' De geschiedenis van het Verbond van Wetenschappelijke Onderzoekers. 1946-1980. Unpublished proefschrift, Universiteit van Amsterdam.

Lewis Mumford. (1963). Technics and Civilization. San Diego: Harcourt Brace Jovanovich.

Lewis Mumford. (1970). The Pentagon Of Power. The Myth of the Machine ( 2nd ed. Vol. 2). San Diego: Harcourt Brace Jovanovich, Publishers.

Lolle Nauta. (1995). Waar is democratie goed voor? In L. Nauta (Ed.), De open samenleving en haar vrienden. Meppel, Amsterdam: Boom.

Lolle Nauta, \& Gerard de Vries (Eds.). (1992). De rol van de intellectueel. Een discussie over distantie en betrokkenheid. Amsterdam: Van Gennep.

D. Nelkin (Ed.). (1992). Controversy: Politics of Technical Decisions (3rd ed. ed.). London: Sage Publications.

David F. Noble. (1977). America by Design: Science, Technology and the Rise of Corporate Capitalism. New York: Knopf.

David F. Noble. (1979). Social Choice in Machine Design: The Case of Automatically Controlled Machine Tools. In A. Zimbalist (Ed.), Case Studies on the Labor Process (pp. 18-50). New York: Monthly Review Press.

W.F. Ogburn, with the assistance of S.C.Gilfillan. (1933). The Influence of Invention and Discovery. In P. s. R. C. o. S. Trends (Ed.), Recent Social Trends in the United States (pp. 122-166). New York: McGraw-Hill Book Company. 
Charles Piller. (1991). The Fail-Safe Society: Community Defiance and the End of American Technological Optimism. Berkeley, CA: University of California Press.

Neil Postman. (1992). Technopoly: the surrender of culture to technology. New York: Random House.

Rathenau-Instituut. (1994a). Het publiek debat: praktijk, ethiek en methodiek (Werkdocument W41): Rathenau Instituut.

Rathenau-Instituut. (1994b). Werkprogramma Rathenau Instituut 1995-1996.: Rathenau Instituut.

James Lee Ray. (1995). Global Politics ( 6th ed.). Boston: Houghton Mifflin Co.

Arie Rip, Thomas J. Misa, \& Johan Schot (Eds.). (1995). Managing Technology in Society. The approach of Constructive Technology Assessment. London: Pinter Publishers.

Jan \& Annie Romein. (1934 (1973)). De lage landen bij de zee. Een geschiedenis van het Nederlandse volk. Amsterdam: EM. Querido's Uitgeverij.

Charles E. Rosenberg. (1987). The Cholera Years. The United States in 1832, 1849, and 1866 ( 2 nd ed.). Chicago: The University of Chicago Press.

Joan Rothschild (Ed.). (1983). Machina Ex Dea: Feminist Perspectives on Technology. New York: Pergamon Press.

J. W. Schot. (1992). Constructive Technology assessment and Technology Dynamics: The Case of Clean Technologies. Science, Technology, \& Human Values, 17, 36-56.

M. Schwarz, \& M. Thompson. (1990). Divided We Stand. Redefining Politics, Technology and Social Choice. London: Harvester Wheatsheaf.

Michiel Schwarz. (1994). Dilemma's van de technologische cultuur. Paper presented at the Wetenschapscultuur en wetenschapscommunicatie in Vlaanderen, Brussel.

Richard Sclove. (1993). Technological Politics as if Democracy really Mattered: Choices Confronting Progressives. In M. Shuman \& J. Schweig (Eds.), Technology for the Common Good (pp. 54-79). Washington, DC: Institute for Policy Studies.

Richard E. Sclove. (1983). Energy Policy and Democratic Theory. In D. S. Zinberg (Ed.), Uncertain Power. The Struggle for 
a National Energy Policy (pp. 37-65). New York: Pergamon Press.

M. Smith, \& L. Marx (Eds.). (1994). Does Technology Drive History? The Dilemma of Technological Determinism. Cambridge, MA: The MIT Press.

R. Smits, \& J. Leyten. (1991). Technology Assessment: Waakhond of Speurhond? Naar een integraal technologiebeleid., Vrije Universiteit Amsterdam.

Sharon Traweek. (1988). Beamtimes and Lifetimes: the World of High Energy Physicists. Cambridge MA: Harvard University Press.

Rein de Wilde, \& Annemarie Mol (Eds.). (1991). Op de grens. Onderzoek naar het scheiden van natuur en cultuur ( Vol. 15). Meppel: Boom.

Rosalind Williams. (1990). Notes on the Underground: An Essay on Technology, Society, and the Imagination. Cambridge, MA: MIT Press.

Rosalind Williams. (1994). The Political and Feminist Dimensions of Technological Determinism. In M. R. Smith \& L. Marx (Eds.), Does Technology Drive History? The Dilemma of Technological Determinism (pp. 217-235). Cambridge, MA: MIT Press.

WRR. (1994). Besluiten over grote projecten (Rapport aan de regering 46): Wetenschappelijke Raad voor het Regeringsbeleid.

Brian Wynne. (1982). Rationality and Ritual: The Windscale Inquiry and Nuclear Decisions in Britain. Chalfont St. Giles: The British Society for the History of Science.

Brian Wynne. (1987). Risk management and Hazardous Wastes: Implementation and the Dialectics of Credibility. London: Springer.

Brian Wynne. (1995). Public Understanding of Science. In S. Jasanoff \& G. E. Markle \& J. C. Petersen \& T. Pinch (Eds.), Handbook of Science and Technology Studies (pp. 361-388). London: Sage. 
colofon

ISBN 90 - 9008200 - X

Druk: Schrijen-Lippertz bv, Voerendaal

(C) 1995 Wiebe E. Bijker, Eijsden 